Zagazig J. Agric. Res., Vol. 43 No. (6B) 2016

http:/www.journals.zu.edu.eg/journalDisplay.aspx? Journalld=1\&queryType=Master

\title{
UTILIZATION OF DATE SYRUP (DIPS) IN PRODUCTION OF FLAVOURED YOGHURT
}

\author{
Rania M.A. Moustafa ${ }^{*}$ E.M. Abdelwahed, A.A. El-Neshwy and Sohir N. Taha \\ Food Sci. Dept., Fac. Agric., Zagazig Univ., Egypt
}

\begin{abstract}
Date syrup was used in the preparation of flavoured yoghurt from whole buffaloes milk. Flavoured yoghurt was made from buffaloes milk supplemented with date syrup at levels of 0.0, 6.0, 8.0 and $10 \%$. Resultant yoghurt of all treatments was stored at $5^{\circ} \mathrm{C}$ for 15 days during which samples were taken for chemical, microbiological and sensory analyses. Addition of date syrup (Dips) to buffaloes milk increased acidity, total solids, total proteins and ash content of resultant flavoured yoghurt, but decreased both fat content and $\mathrm{pH}$ values. Also date syrup addition decreased total bacterial count and increased lactobacilli count of resultant flavoured yoghurt. These observations were associated with the level of date-syrup addition. Yeasts, moulds and coliforms counts were some slight higher in flavoured yoghurt but within the legal Egyptian standards. Results also indicated that addition of dips to buffaloes milk up to $8 \%$ greatly improved the organoleptic properties of resultant flavoured yoghurt either when fresh or up to the end of the storage period. But increasing the level of dips more than $8 \%$ decreased the scores of resultant product. So, it could be concluded that the best level of dips addition was $8 \%$ in order to produce good quality date- syrup flavoured yoghurt.
\end{abstract}

Key words: Utilization, date syrup (dips), flavoured yoghurt.

\section{INTRODUCTION}

Palm date is a rich source of carbohydrates, most of which is in the form of simple sugars. According to the United States Department of Agriculture (USDA) National Nutrient Database, a $100 \mathrm{~g}$ serving of dates provides almost $75 \mathrm{~g}$ of carbohydrates, which accounts for $18 \%$ of the daily value for carbohydrates. About $85 \%$ of total carbohydrate in dates is present in the form of simple sugars. Date proteins were found to be rich in acidic amino acids and poor in sulfur containing amino acids such as methionine and cysteine. Within the same stage of maturation, the amino acid content varies significantly. Amino acids content increased in dried varieties mainly due to water reduction (Auda et al. 1976). Al-Hooti et al. (1997) reported that dates contain high levels of protein compared to most other fruits. The highest content is observed during Kimri phase (5.5-6.4\%), which gradually decreases to $2-2.5 \%$ during the Tamar stage. The flesh of date also contains $0.2-0.5 \%$ oil, while the seeds contain $7.7-9.7 \%$ oil.

Date pulp contains vitamins such as riboflavin, thiamine, biotin, folic acid, and ascorbic acid that are essential for the body. Dates are rich in B-complex vitamins, such as thiamine (B1), riboflavin (B2), niacin (B3), pantothenic acid (B5), pyridoxine (B6), and folate (B9) and vitamin $\mathrm{K}$ (Al-Farsi and Lee, 2008). It is worth mentioning that some vitamins (B3, B5, B6, and B9) are found in higher concentrations in dates than some common fruits like apple, orange, and berries. The niacin content is very high and it varies between 1.27 and $1.61 \mathrm{mg} / 100 \mathrm{~g}$. Quantitative analysis of water-soluble vitamins (B1, B2, B3, B5, B6, B9, B12) showed a significant variation within the different cultivars and the developing stages of date fruit

* Corresponding author: Tel. : +201069471742

E-mail address: raniadawoud22@gmail.com 
(Aslam et al. 2011). Vitamins B1, B3, B5 and B6 are highest in mature stages; however, vitamins B2, B9 and B12 have been detected in immature fruit. Vitamin $\mathrm{C}$ content is found to be very low in dates.

Also dates contain essential minerals, for example, potassium, which is essential for muscle contractions and helps to control heart rate and blood pressure (Al-Shahib and Marshall 2002). One hundred grams of date contains 696 $\mathrm{mg}$ of potassium, $90 \mathrm{mg}$ of iron, $362 \mathrm{mg}$ of copper, and $90 \mathrm{mg}$ of magnesium, which are essential for bone growth. Also, copper is needed for the production of red blood cells. The significantly high potassium and low sodium contents in dates are optimum for people suffering from hypertension (Appel et al., 1997). According to El Hadrami and Al-Khayri (2012) the date fruit contains fluorine, which is proven to protect against tooth decay. Also, selenium which has many functions in the human body; it can prevent cancer and stimulate the immune system. Dates are a good source of iron and can correct iron deficiencies and anemia. In addition to being a rich source of carbohydrates, dietary fibers, some essential vitamins, and minerals, dates are also rich in a variety of phytochemicals, for example, phenolics, sterols, carotenoids, anthocyanins, procyanidins, and flavonoids. Even date pits are an excellent source of phytochemicals besides dietary fiber, minerals, lipids, and protein. In addition to their pharmacological properties, phytochemicals also contribute to nutritional and sensorial properties of dates. Phytochemicals in fruits have been shown to possess significant antioxidant capacities that may be associated with lower incidence and lower mortality rates of degenerative diseases in human (Baliga et al., 2011; Vayalil 2012).

Date has been considered as a source of antioxidants. Antioxidants inhibit oxidative mechanisms that lead to do generative diseases such as heart disease, brain dysfunction and arthritis (Prior et al., 1999). Dates are reported to have antitumor activity, antimutagenic properties, and can lower the rate of cancers, especially pancreatic cancer and activate immune system and regulate the role of antibiotics (Ishurd and Kennedy, 2005; Vayalil, 2012). An aqueous extract of date flesh has potent free radical scavenging activity of reactive oxygen species like superoxide and hydroxyl radicals. The same extract also showed a strong inhibitory effect on in vitro macromolecular damages such as lipid peroxidation and protein oxidation.

Date palm products were used in the manufacture of some dairy products.. Flavoured yoghurts are made by adding fruit concentrates or flavours to cultured milk before or after incubation (Keating and White, 1990). Dates are of higher nutritional value and do not need the addition of sugar or colours and flavours, compared to other fruits

Hashim (2001) studied the characteristics and acceptability of yoghurt containing date palm products. Results indicated that addition of $10-20 \%$ of date paste with or without $5 \%$ date syrup did not affect yoghurt acidity, protein or fat contents, but increased total solids significantly. Yoghurt is most often flavoured with fruit preserves or other ingredients (Potter and Hotchkiss, 1995).

Hashim et al. (2009) investigated the effect of fortification with date fibers on quality of yoghurt. Fortification of fresh yoghurt with $1.5 \%, 3.0 \%$ and $4.5 \%$ date fiber did not cause significant changes in yoghurt acidity, although the $\mathrm{pH}$ was increased. Yoghurt fortified with date fiber had firmer texture (higher hardness values) and darker colour. Sensory ratings and acceptability of yoghurt decreased significantly when date fibers increased to $4.5 \%$. Fortifying yoghurt with $3 \%$ date fibers produced acceptable yoghurt with beneficial health effects.

Gad et al. (2010) used date fruit as a part of water $(V / V)$ used in reconstituting skimmed milk powder in processing yoghurt with $14 \%$ total solids. Results showed that yoghurt enriched with $10 \%$ dates had a significant sweetness, recorded the highest antioxidant values, higher in $\mathrm{HCl}$ - soluble minerals and folate concentration compared to plain yoghurt. It could be concluded that numerous health benefits beyond its nutritional value have been associated with consuming yoghurt enriched with $10 \%$ date fruit.

Al-Jasass et al. (2010) produced date flavoured probiotic stirred yoghurt from both fresh cow milk and reconstituted whole milk powder. They found that the addition of date 
syrup to the probiotic yoghurt enhanced the bifidobacterial count of the product and improved their survival during the cold storage period up to 10 days. This could be explained on the basis that date syrup may contain some micronutrients, such as vitamins and minerals, which might enhance the growth of bifidobacteria.

The present study aimed to utilize datesyrup (Dips) as a natural source of sweeteners, colours and flavouring agents in the production of flavoured yoghurt.

\section{MATERIALS AND METHODS}

\section{Materials}

\section{Milk}

Fresh buffaloes milk (6\% fat) used during this study was obtained from Dairy unit, Faculty of Agriculture, Zagazig University, Egypt.

\section{Yoghurt Cultures}

Streptococcus salivarius ssp. thermophilus (EMCC1044=DSM20479) and Lactobacillus delbrueckii ssp. bulgaricus (EMCC1102 = DSM20080) were used as a yoghurt starter. These strains were obtained from Egyptian Microbial culture collection of Cairo MIRCEN (EMCC), Faculty of Agriculture, Ain Shams, University, Egypt.

Streptococcus salivarius ssp. thermophilus. was revived by a series of two inoculations into $10 \mathrm{ml}$ of Ml7 broth and incubated aerobically at $37^{\circ} \mathrm{C}$ for $48 \mathrm{hr}$., and L. delbrueckii ssp. bulgaricus was inoculated into MRS broth and incubated at $42^{\circ} \mathrm{C}$ for $48 \mathrm{hr}$., in anaerobic chamber .

The stock cultures were maintained at $-20^{\circ} \mathrm{C}$ in $12 \%(W / W)$ reconstituted skim milk (RSM) and $40 \%(V / V)$ sterile glycerol. The microorganisms were activated by growing in $10 \%(\mathrm{~W} / \mathrm{W})$ sterile RSM for $18 \mathrm{hr}$., consequently 3 times prior to yoghurt manufacture. Commercial date syrup (Dips) was collected from local market at Zagazig City.

\section{Preparation of date syrup flavoured yoghurt}

Fresh whole buffaloes milk was heated at $90^{\circ} \mathrm{C}$ for $15 \mathrm{~min}$, cooled to $40^{\circ} \mathrm{C}$ then divided into 4 equal portions. Each portion was stirred with different levels of cooled pasteurized date syrup $(0.0,6.0,8.0$ and 10\%). Milk of all treatments was then inoculated with $2 \%$ of yoghurt culture and filled in plastic cups $(100 \mathrm{ml}$ each), incubated at $40^{\circ} \mathrm{C}$ till complete coagulation (about 4 hours) and then stored at $4^{\circ} \mathrm{C}$ for 15 days. Samples for chemical, microbiological analyses and sensory evaluation were taken after $0,3,7,10$ and 15 days.

\section{Methods of analyses}

Flavoured yoghurt samples were chemically analyzed for: total solids, fat, total protein, $\mathrm{pH}$ and acidity according to AOAC (2000).

\section{Microbiological Examinations}

\section{Enumeration of lactobacilli strain}

The total bacterial count of flavoured yoghurt Ras cheese was determined according to (American Public Health Association, 1992b) using Tryptone Glucose Extract Agar (T.G.E.A) medium; plates were incubated at $37^{\circ} \mathrm{C}$ for 2 to 3 days.

\section{Enumeration of lactobacilli strain}

MRS agar (Oxoide Ltd. Basingstoke, UK, 1965) with pH $6.2 \pm 0.1$ was used for enumeration of Lactobacillus delbrueckii subsp. bulgaricus according to Dave and Shah (1996). The plates were incubated at $42^{\circ} \mathrm{C}$ for $72 \mathrm{hr}$. Anaerobic culture jars (2.5 l) were employed to generate anaerobic conditions, atmospheric oxygen being absorbed by means of AnaeroGen AN 25 sachets (Oxoid, 1965). The counts were expressed as $\times 10^{6} \mathrm{cfu} / \mathrm{gm}$. The lactobacilli identified on the basis of colonial type were confirmed by microscopic examination. The genus Lactobacillus was Gram positive rods with rounded ends.

\section{Enumeration of coliform counts}

Total coliforms count was estimated by plating suitable dilution on Violet red bile agar medium (VRBA) (Oxoide Ltd. Basingstoke, UK, 1965) as described by American Public Health Association (1992a). The plates were incubated at $35^{\circ} \mathrm{C}$ for $24 \mathrm{hr}$., and the small nonmucous red colonies were counted. 


\section{Enumeration of moulds and yeasts}

Moulds and yeasts were enumerated on acidified potato dextrose agar medium (Difco, 1984). Plates were incubated at $25^{\circ} \mathrm{C}$ for $4-5$ days.

\section{Sensory evaluation}

The Sensory evaluation for the flavoured yoghurt samples was done by panelists from the staff members of Food Science Department, Faculty of Agriculture, Zagazig University according to Nelson and Trout (1981).

\section{RESULTS AND DISCUSSION}

\section{Acidity and pH}

Results presented in Table 1 indicate that addition of date syrup to buffaloes milk enhanced the development of acidity during yoghurt fermentation. So it could be noticed that date-syrup flavoured yoghurt showed higher acidity than control one. This could be explained on the basis that date-syrup had higher contents of simple sugars and some micronutrients, such as vitamins and minerals, which might enhance the growth of bifidobacteria and yoghurt culture (Al-Farsi and Lee, 2008). This increase in flavoured yoghurt acidity was associated with a decrease in $\mathrm{pH}$ values of resultant product. Acidity contents of yoghurt of all treatments slightly increased during storage period and this was associated with a gradual decrease in $\mathrm{pH}$ values. The general trend of these results are in agreement with those reported by Hashim (2001) and Al-Jasass et al. (2010).

\section{Chemical Composition of Resultant Yoghurt}

Results of total solids, total proteins, ash and fat contents of resultant yoghurt of all treatments are shown in Tables 2 and 3 data indicated that addition of date syrup to buffaloes milk resulted in increasing total solids, total protein and ash contents of resultant flavoured yoghurt to be higher than control yoghurt. This was associated with a slight decrease in fat content. Also this effect was more noticed with the increase of level of date syrup addition. The increase in total solids, total protein and ash contents could be due to the higher total solids of date syrup which also had higher ash content. Moreover date syrup contain also proteins (Auda et al., 1976; Al-Hooti et al., 1997). The decrease in fat contents could be due to the increase in the other solids nonfat contents. Moreover both total solids, total proteins, ash and fat contents of yoghurt of all treatments were slightly increased with the advance of storage period .Similar results were reported by Hashim et al. (2009) and Al-Jasass et al. (2010).

\section{Bacterial Contents}

Results presented in Table 4 shows the total bacterial count and total lactobacilli count of resultant date- syrup flavoured yoghurt during storage period. Results indicated that addition of date syrup reduced the total bacterial count of resultant flavoured yoghurt and this was associated with the level of addition These results could be due to the higher level of sugars presented in date- syrup yoghurt which resulted in enhancing acidity development and this may delete the growth rate of some microorganisms. However the total lactobacilli count showed the opposite trend whereas the addition of datesyrup resulted in increasing the lactobacilli count of resultant yoghurt. This could be explained on the basis that date syrup may contain some micronutrients, such as vitamins and minerals, which might enhance the growth and activity of yoghurt culture (Al-Farsi and Lee, 2008). These results confirmed those noticed for acidity content of the resultant flavoured yoghurt which was higher than control one (Table 1). Also lactobacilli may tolerate higher acidity than other microorganisms. Moreover it could be noticed that both total bacterial and lactobacilli count of yoghurt of all treatments gradually increased during storage period. The general trend of these results are in agreement with those reported by Hashim (2001) and Gad et al. (2010). 
Zagazig Journal of Food and Dairy Research

Table 1. Acidity and $\mathrm{pH}$ values of date-syrup flavoured yoghurt during storage at $5^{\circ} \mathrm{C}$ for 15 days

\begin{tabular}{|c|c|c|c|c|c|c|c|c|}
\hline \multirow[b]{2}{*}{ Treatment } & \multicolumn{4}{|c|}{ Acidity (\%) lactic acid } & \multicolumn{4}{|c|}{$\mathbf{p H}$} \\
\hline & 0.0 & 5 & 10 & 15 & 0.0 & 5 & 10 & 15 \\
\hline$\overline{\text { Control }}$ & 0.84 & 0.92 & 1.06 & 1.10 & 5.64 & 4.61 & 4.11 & 4.10 \\
\hline $6 \%$ date syrup & 0.86 & 0.99 & 1.06 & 1.20 & 5.41 & 4.51 & 4.30 & 3.89 \\
\hline $8 \%$ date syrup & 0.84 & 0.88 & 1.02 & 1.14 & 5.69 & 4.50 & 4.18 & 3.90 \\
\hline $10 \%$ date syrup & 0.76 & 0.91 & 1.04 & 1.08 & 5.67 & 4.48 & 4.10 & 4.08 \\
\hline
\end{tabular}

Table 2. Total solids and total protein contents of date-syrup flavoured yoghurt during storage at $5^{\circ} \mathrm{C}$ for 15 days

\begin{tabular}{|c|c|c|c|c|c|c|c|c|}
\hline \multirow[b]{2}{*}{ Treatment } & \multicolumn{4}{|c|}{ Total solids (\%) } & \multicolumn{4}{|c|}{ Total protein (\%) } \\
\hline & 0.0 & 5 & 10 & 15 & 0.0 & 5 & 10 & 15 \\
\hline$\overline{\text { Control }}$ & 14.92 & 14.98 & 15.12 & 15.21 & 3.82 & 3.93 & 4.08 & 4.11 \\
\hline $6 \%$ date syrup & 19.42 & 19.86 & 20.04 & 20.11 & 4.77 & 4.96 & 5.11 & 5.23 \\
\hline $8 \%$ date syrup & 20.93 & 21.08 & 21.16 & 21.35 & 4.95 & 5.22 & 5.36 & 5.42 \\
\hline $10 \%$ date syrup & 21.82 & 22.23 & 22.41 & 22.73 & 5.26 & 5.42 & 5.64 & 5.81 \\
\hline
\end{tabular}

Table 3. Fat and ash contents of date-syrup flavoured yoghurt during storage at $5^{\circ} \mathrm{C}$ for 15 days

\begin{tabular}{|c|c|c|c|c|c|c|c|c|}
\hline \multirow[b]{2}{*}{ Treatment } & \multicolumn{4}{|c|}{ Fat (\%) } & \multicolumn{4}{|c|}{ Ash (\%) } \\
\hline & 0.0 & 5 & 10 & 15 & 0.0 & 5 & 10 & 15 \\
\hline$\overline{\text { Control }}$ & 6.0 & 6.2 & 6.5 & 6.6 & 0.89 & 0.93 & 0.95 & 0.98 \\
\hline $6 \%$ date syrup & 5.8 & 5.9 & 6.0 & 6.1 & 0.98 & 1.05 & 1.09 & 1.10 \\
\hline $8 \%$ date syrup & 5.6 & 5.7 & 5.8 & 6.0 & 1.11 & 1.17 & 1.21 & 1.23 \\
\hline $10 \%$ date syrup & 5.4 & 5.6 & 5.7 & 5.9 & 1.20 & 1.24 & 1.27 & 1.30 \\
\hline
\end{tabular}

Table 4. Total bacterial and lactobacilli bacterial count of date-syrup flavoured yoghurt during storage at $5^{\circ} \mathrm{C}$ for 15 days

\begin{tabular}{|c|c|c|c|c|c|c|c|c|}
\hline \multirow[b]{2}{*}{ Treatment } & \multicolumn{4}{|c|}{$\begin{array}{l}\text { Total bacterial count } \\
\qquad\left(\times 10^{6} \mathrm{cfu} / \mathrm{g}\right)\end{array}$} & \multicolumn{4}{|c|}{$\begin{array}{l}\text { Lactobacilli bacterial count } \\
\qquad\left(\times 10^{6} \mathrm{cfu} / \mathrm{g}\right)\end{array}$} \\
\hline & 0.0 & 5 & 10 & 15 & 0.0 & 5 & 10 & 15 \\
\hline Control & 146 & 165 & 260 & 310 & 46 & 55 & 73 & 130 \\
\hline $6 \%$ date syrup & 118 & 142 & 225 & 289 & 57 & 63 & 111 & 121 \\
\hline $8 \%$ date syrup & 111 & 138 & 205 & 265 & 70 & 92 & 114 & 138 \\
\hline $10 \%$ date syrup & 98 & 118 & 189 & 216 & 91 & 112 & 141 & 163 \\
\hline
\end{tabular}




\section{Moulds and Yeast and Coliform Counts}

Data in Table 5 show the counts of yeast, moulds and coliform of flavoured yoghurt. Data indicated that flavoured yoghurt had higher yeast count either when fresh or after 15 days of storage (Table 5). This could be due to the higher sugar content of date syrup which may enhance yeast growth. Also it could be noticed that moulds were not detected in fresh samples of all treatments, but counts of moulds at 15 days stored flavoured yoghurt samples were slightly higher than control one. Coliforms were not detected in flavoured yoghurt samples when fresh or after 15 days of storage. Meanwhile counts of yeasts, moulds and coliforms in all samples were in accordance to the legal Egyptian standards.

\section{Whey Syneresis of Flavoured Yoghurt}

Results presented in Table 6 show the effect of date syrup addition on whey syneresis in flavoured yoghurt. Data indicated that addition of date syrup slightly increased the whey syneresis of resultant yoghurt and this effect associated with the level of date syrup addition. This could be due to enhancing acidity development of yoghurt as reported by Al-Farsi and Lee (2008).

\section{Sensory Evaluation of Resultant Flavoured Yoghurt}

Results presented in Table 7 show the average scores for organoleptic properties of date-syrup flavoured yoghurt during storage period for 15 days at $5^{\circ} \mathrm{C}$. Data indicated that addition of date syrup to buffaloes milk up to $8 \%$ greatly increased the scores given to the resultant flavoured yoghurt. Moreover it could be noticed that addition of date syrup at level of $8 \%$ gained the highest scores. Data show that this treatment (8\% date syrup) showed the highest scores for appearance, body and texture, flavour and total score either at fresh or during the storage period. However increasing the level more than $8 \%$ resulted in decreasing the scores for resultant flavoured yoghurt, whereas more whey was separated due to the higher acidity (Tables 2 and 6). These results are in agreement with those reported by Hashim (2001), Al-jasass et al. (2010) and Gad et al. (2010) who reported that using date syrup (Dips) and date paste improved the organoleptic characteristics of flavoured fermented dairy products.

So, it could be concluded that the best level of dips was $8 \%$ in order to produce good quality date- syrup flavoured yoghurt.

Table 5. Yeasts, moulds and coliform bacterial count of date-syrup flavoured yoghurt during storage at $5^{\circ} \mathrm{C}$ for 15 days

\begin{tabular}{|c|c|c|c|c|c|c|}
\hline \multirow[b]{2}{*}{ Treatment } & \multicolumn{2}{|c|}{$\begin{array}{l}\text { Yeast count } \\
\left(\times 10^{1} \mathrm{cfu} / \mathrm{g}\right)\end{array}$} & \multicolumn{2}{|c|}{$\begin{array}{l}\text { Mould count } \\
\left(\times 10^{1} \mathrm{cfu} / \mathrm{g}\right)\end{array}$} & \multicolumn{2}{|c|}{$\begin{array}{l}\text { Colifom count } \\
\left(\times 10^{1} \mathrm{cfu} / \mathrm{g}\right)\end{array}$} \\
\hline & 0.0 & 15 & 0.0 & 15 & 0.0 & 15 \\
\hline$\overline{\text { Control }}$ & 32 & 40 & ND & 3 & ND & ND \\
\hline $6 \%$ date syrup & 41 & 48 & ND & 5 & ND & ND \\
\hline $8 \%$ date syrup & 44 & 53 & ND & 7 & ND & ND \\
\hline $10 \%$ date syrup & 50 & 61 & ND & 11 & ND & ND \\
\hline
\end{tabular}

ND: Not detected 
Table 6. Whey syneresis of date-syrup flavoured yoghurt during storage at $5^{\circ} \mathrm{C}$ for 15 days

\begin{tabular}{lcccc}
\hline & $\begin{array}{c}\text { Storage period } \\
\text { (day) }\end{array}$ & \multicolumn{4}{c}{ Whey syneresis (ml. whey/100gm) } \\
\cline { 2 - 5 } Treatment & $\mathbf{0 . 0}$ & $\mathbf{5}$ & $\mathbf{1 0}$ & $\mathbf{1 5}$ \\
\hline Control & 35.80 & 35.91 & 36.23 & 37.80 \\
$\mathbf{6 \%}$ date syrup & 36.20 & 36.89 & 37.92 & 38.11 \\
$\mathbf{8 \%}$ date syrup & 37.36 & 37.95 & 38.42 & 39.12 \\
$\mathbf{1 0 \%}$ date syrup & 38.92 & 39.53 & 40.16 & 41.28 \\
\hline
\end{tabular}

Table 7. Sensory evaluation of date-syrup flavoured yoghurt during storage at $5^{\circ} \mathrm{C}$ for 15 days

\begin{tabular}{lccccc}
\hline Treatment & $\begin{array}{c}\text { Storage period } \\
\text { (day) }\end{array}$ & $\begin{array}{c}\text { Appearance } \\
\mathbf{1 0}\end{array}$ & $\begin{array}{c}\text { Body and texture } \\
\mathbf{3 0}\end{array}$ & $\begin{array}{c}\text { Flavour } \\
\mathbf{6 0}\end{array}$ & $\begin{array}{c}\text { Total } \\
\mathbf{1 0 0}\end{array}$ \\
\hline \multirow{3}{*}{ Control } & 0.0 & 9.00 & 25.10 & 50.20 & 84.30 \\
& 5 & 9.10 & 26.00 & 51.00 & 86.20 \\
& 10 & 9.00 & 25.20 & 50.20 & 84.40 \\
& 15 & 8.70 & 24.30 & 49.00 & 82.00 \\
$\mathbf{6 \%}$ Date syrup & 0.0 & 9.20 & 27.00 & 51.60 & 87.80 \\
& 5 & 9.60 & 27.20 & 55.20 & 92.00 \\
& 10 & 8.70 & 27.00 & 53.40 & 89.10 \\
& 15 & 8.40 & 26.20 & 52.70 & 87.30 \\
$\mathbf{8 \%}$ Date syrup & 0.0 & 8.20 & 27.80 & 55.60 & 91.60 \\
& 5 & 8.80 & 27.70 & 56.40 & 92.90 \\
& 10 & 8.80 & 27.40 & 55.40 & 91.60 \\
& 15 & 8.50 & 27.20 & 55.00 & 90.70 \\
$\mathbf{1 0 \%}$ Date syrup & 0.0 & 7.20 & 25.80 & 53.80 & 86.80 \\
& 5 & 8.00 & 25.20 & 52.40 & 85.60 \\
& 10 & 7.50 & 24.90 & 51.00 & 83.40 \\
& 15 & 7.20 & 24.20 & 50.00 & 81.40 \\
\hline
\end{tabular}

\section{REFERENCES}

Al-Farsi, M.A. and C.Y. Lee (2008). Nutritional and functional properties of dates: A review. Crit. Rev. Food Sci. Nutr., 48: 877-87.

Al-Hooti, S., J.S. Sidhu and H. Qabazard (1997). Physicochemical characteristics of five date fruit cultivars grown in the United Arab Emirates. Plant Foods Human. Nutr., 50:101-03.

Al-Jasass, F.M., S.M. Aleid and A.A. ElNeshwy (2010). Utilization of dates in the manufacture of new probiotic dairy food. First annual report, Date Palm Res. Cent., King Faisal Univ., Al-Ahsa, Project, PR3.
Al-Shahib, W. and R.J. Marshall (2002). Dietary fiber content of dates from 13 varieties of date palm Phoenx dactylifera L. Int. J. Food Sci. Technol., 37: 719-21.

American Public Health Association (1992a). Compendium of Methods for the Microbiological Examination of Foods, $3^{\text {rd }}$ Ed. APHA, Wasington, DC.

American Public Health Association (1992b). Standard Methods for the Examination of Dairy products, Inc. $16^{\text {th }} \mathrm{Ed}$. New York.

AOAC (2000). Association of Official Analytical Chemists, Official Methods of Analysis, $17^{\text {th }}$ Ed., Gaithersburg, MD, USA. 
Appel, L., J. Moore and T.J. Obarzanek (1997). A clinical trial of the effects of dietary patterns on blood pressure. New Eng. J. Med., 336: 1117-24.

Aslam, J., S.H. Khan and S.A. Khan (2011). Quantification of water soluble vitamins in six date palm (Phoenix dactylifera L.) cultivar's fruits growing in Dubai, United Arab Emirates, through high performance liquid chromatography. J. Saudi Chem. Soc., $17: 9-16$

Auda, H., H. Al-Wandawi and L. Al-Adhami (1976). Protein and amino acid composition of three varieties of Iraqi dates at different stages of development. J. Agric. Food Chem., 24: 365-72.

Baliga, M.S., B.R.V. Baliga, S.M. Kandathil, H.P. Bhat and P.K. Vayalil (2011). A review of the chemistry and pharmacology of the date fruits (Phoenix dactylifera L.). Food Res. Int., 44 : 1812-22.

Difco, M. (1984). Difco Manual of dehydrated culture Media and Reagent. Difco Laboratories, Ed. Detroit, Michigan USA.

Dave, R. I. and N. P. Shah (1996). Evaluation of media for selective enumeration of Streptococcus thermophilus, Lactobacillus delbrueckii ssp. bulgaricus, Lactobacillus acidophilus and Bifidobacterium spp. J. Dairy Sci., 79: 1529-1 536.

El Hadrami, A. and J.M. Al-Khayri (2012). Socio economic and traditional importance of date palm. Emir. J. Food Agric., 24 : 371-85.

Gad, A.S., A.M. Kholif and A.F. Sayed (2010). Evaluation of the nutritional value of functional yoghurt resulting from combination of date palm syrup and skim milk. Ame. J. Food Technol., 5: 250 - 259.

Hashim, I.B. (2001). Characteristics and acceptance of yoghurt containing date palm products. In: Second international conference on date palms, Al-Ain, United Arab Emir., 25 (26): 842-849.

Hashim, I.B., A.H. Khalil and H. Habib (2009). Quality and acceptability of a set-type yoghurt made from camel milk. J. Dairy Sci., 92: 857-862.

Ishurd, O. and J.F. Kennedy (2005). The anticancer activity of polysaccharide prepared from Libyan dates. Carbohyd Polym., 59: 531-5.

Keating, K. and C.H. White (1990). Effect of alternative sweeteners in plain and fruit flavoured yoghurt. J. Dairy Sci., 73: 54-62.

Nelson, J.A. and G.M. Trout (1981). Judging of Dairy Products. Avi. Publishing company, Inc. Westport, Connecticut, 60.

Oxoid Mannual of Culture Media, Ingredients and other Laboratory Services (1965). "Published by Oxoid limited". Southwark Bridge Road, London.

Potter, N.N. and J.H. Hotchkiss (1995). Milk and Milk Products in Food Science, $5^{\text {th }}$ Ed. Chapman and Hall, New York.

Prior, R.L., J.A. Joseph, G. Cao and B. SukittHalle (1999). Can foods forestall aging. Agric. Res., 47:15-7.

Vayalil, P.K. (2012). Date Fruits (Phoenix dactylifera L.): an emerging medicinal food. Crit. Rev. Food Sci. Nutr., 52: 249-71. 


\section{اســتخدام دبس التمـــور في إنتاج يوغـــورت منـــــهـ}

$$
\begin{aligned}
& \text { رإنيا محمد عبدالحي مصطفى - السيد محمد عبدالواحد }
\end{aligned}
$$

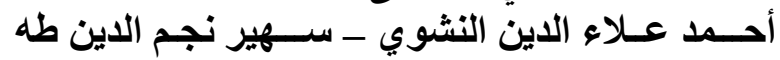

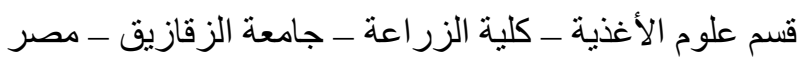

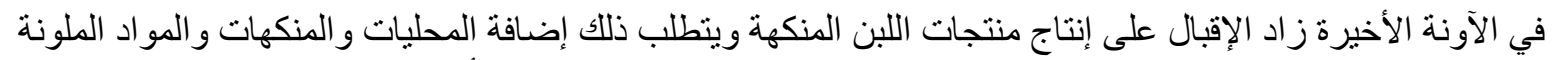

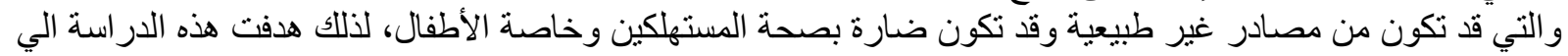

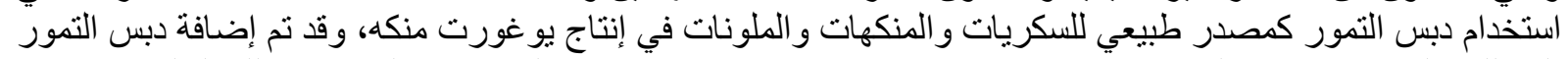

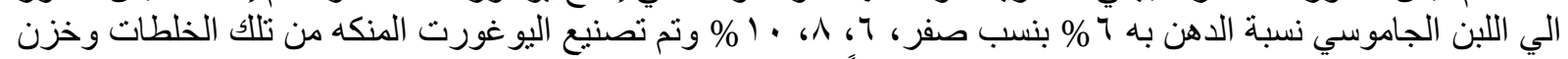

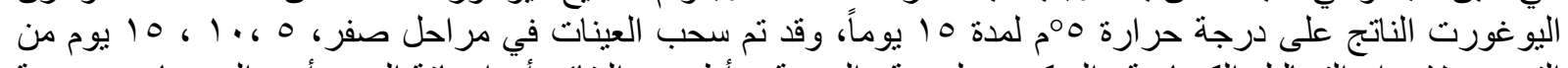

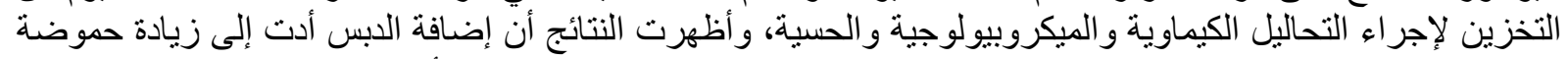

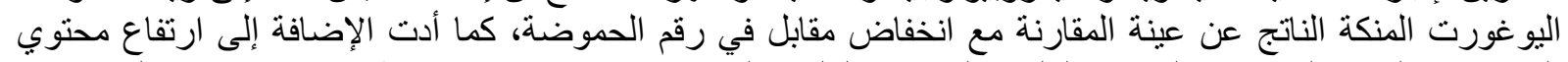

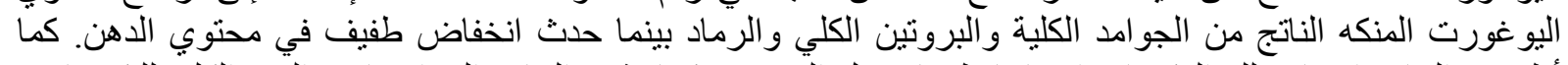

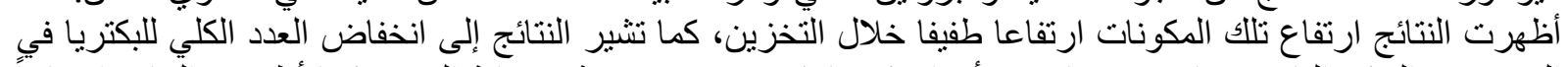

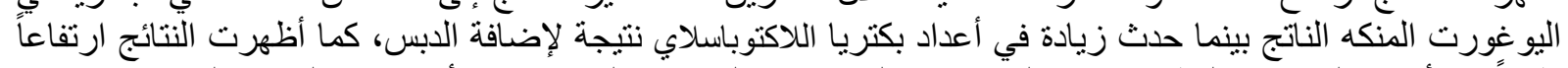

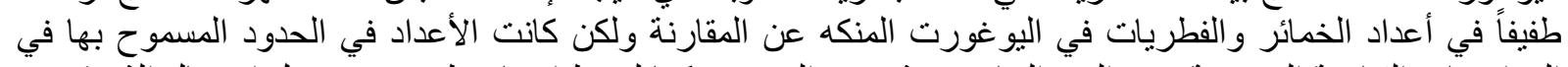

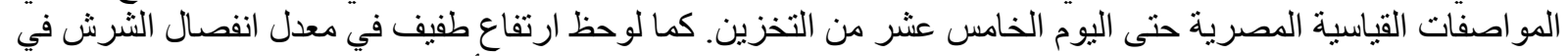

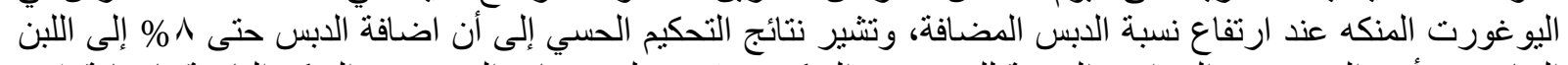

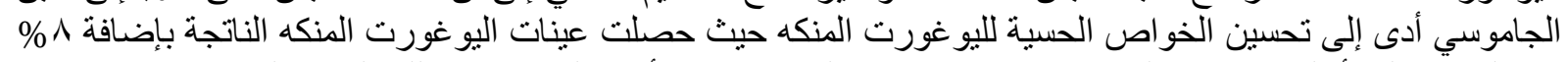

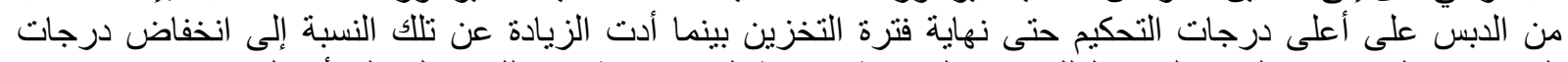

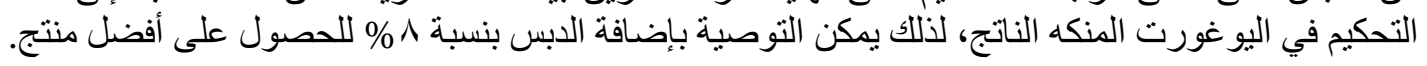

